\title{
Evaluating a Recycled Food Waste-Based Liquid Compost in Conventional California Strawberries
}

\author{
Surendra K Dara* \\ University of California Cooperative Extension, USA
}

Submission: September 23, 2016; Published: October 30, 2017

"Corresponding author: Surendra K Dara, University of California Cooperative Extension, San Luis Obispo, CA, USA, 93401, Tel: 805-7201700;

Email: skdara@ucdavis.edu

\begin{abstract}
A study was conducted in 2013 on a commercial strawberry field using a new formulation of a liquid compost based on recycled food waste from grocery stores. Liquid compost alone, grower's propriety regimen of synthetic fertilizers, and their combination (50:50) were applied through drip irrigation system on three dates. Marketable strawberry yields from 10 harvest dates showed that liquid compost alone and in combination with the grower standard improved the yields compared to the grower standard regimen.
\end{abstract}

Keywords: Strawberry; Nutrient management; Liquid compost

\section{Introduction}

Synthetic or chemical or inorganic fertilizers are commonly used in many conventional crop production systems providing essential nutrients necessary for optimal plant growth and yields. While they provide the plants with readily available nutrients, excessive application could lead to leaching into the ground water, promote vegetative growth, or increase the attractiveness of plants to pests and diseases. Organic fertilizers, on the other hand, are generally made from plant or animal sources. Compared to synthetic fertilizers where nutrients are readily available, nutrients are slowly released from organic fertilizers and have a lower risk of nutrient leaching. Organic fertilizers add organic matter to the soil, which improves soil structure, water holding capacity, and root growth. Organic matter also supports beneficial microbial communities in the soil that improve nutrient availability to the plant and protect plants from plant pathogens and other stress factors.

Organic fertilizers, especially those made from food waste, have a significant environmental benefit by recycling valuable nutrient and energy resources that would have, otherwise, been wasted [1]. Several studies emphasized the importance of soil organic matter and its positive impact on soil fertility, crop productivity, and environmental sustainability [2-4]. However, a balanced use of both synthetic and organic fertilizers is a good strategy both to meet plant needs and environmental sustainability [5].
In the United States, food waste at consumer and retail levels was estimated to be about $30 \%$ of the food supply, which is equal to 133 billion pounds valued at $\$ 161$ billion [6]. Converting this food waste into a fertilizer will have a major impact on the agriculture as food waste is the largest part of the landfills and is the third largest source of methane in the United States. To evaluate the efficacy of a recycled food waste-based liquid compost on strawberry yield, a study was conducted during the spring of 2013 on a conventional strawberry field at DB Specialty Farms, Santa Maria.

\section{Materials and Methods}

Harvest-to-Harvest $(\mathrm{H} 2 \mathrm{H})$, made by hydrolysis of freshly expired produce, meat, and other food items collected from grocery stores, was evaluated alone and in combination with the grower standard. The formulation of $\mathrm{H} 2 \mathrm{H}$ used in the study had NPK at $1-1-0,5-7 \%$ of amino acids, $6-8 \%$ of lipids, $8-10 \%$ carbohydrates, and $20-25 \%$ organic matter according to the label. Treatments included

i) Grower standard or GS (proprietary fertilizer regimen).

ii) $\mathrm{H} 2 \mathrm{H}$ at 73 gallons/acre, and

iii) $\mathrm{H} 2 \mathrm{H}: \mathrm{GS}$ at 50:50. $\mathrm{H} 2 \mathrm{H}$ was administered through the drip irrigation system 28 March, 9 and 18 April. Each treatment had a block of about 1.6 acre that were adjacent to each other. 
On six randomly selected beds within each block, a 40-plant section was marked as a sampling plot. Yield data were collected from these plots from 4 April to 20 May on 10 sampling dates following grower's harvest schedule.

\section{Results and Discussion}

Compared to the yield in GS plots, marketable strawberry yield was significantly higher $(\mathrm{P}<0.05)$ for $\mathrm{H} 2 \mathrm{H}$ treatment on Table 1: Marketable strawberry yields on 10 harvest date. four of the harvest dates and for GS: $\mathrm{H} 2 \mathrm{H}$ combination on two of the harvest dates (Table 1 ). The average marketable berry yield was significantly higher $(\mathrm{P}=0.0003)$ in both $\mathrm{H} 2 \mathrm{H}$ and $\mathrm{GS}$ : $\mathrm{H} 2 \mathrm{H}$ treatments compared to the GS treatment (Figure 1). There was no difference $(\mathrm{P}=0.283)$ in the weight of unmarketable berries and their proportion of the total yield was $18.7,15.5$, and 16.2 for GS, $\mathrm{H} 2 \mathrm{H}$, and GS: $\mathrm{H} 2 \mathrm{H}$, respectively.

\begin{tabular}{|c|c|c|c|c|c|c|c|c|c|c|}
\hline \multirow{2}{*}{ Treat- ment } & \multicolumn{10}{|c|}{ Marketable Strawberry Yield Per Plot(g) } \\
\hline & 4-Apr-13 & 8-Apr-13 & 11-Apr-13 & 15-Apr-13 & 18-Apr-13 & 22-Apr-13 & 25-Apr-13 & 29-Apr-13 & 2-May-13 & 20-May-13 \\
\hline GS & $115.3 \pm 19.1 \mathrm{~b}^{*}$ & $674.7 \pm 59.6 \mathrm{a}$ & $444.3 \pm 65.1 \mathrm{a}$ & $475.0 \pm 66.9 \mathrm{~b}$ & $514.8 \pm 89.7 \mathrm{a}$ & $767.3 \pm 151.2 \mathrm{a}$ & $260.8 \pm 43.8 \mathrm{~b}$ & $682.0 \pm 71.7 \mathrm{~b}$ & $265.2+34.8 b$ & $490.2+30.7 b$ \\
\hline $\mathrm{H} 2 \mathrm{H}$ & $493.5 \pm 70.9 \mathrm{a}$ & $736.3 \pm 44.5 \mathrm{a}$ & $546.8 \pm 59.5 a$ & $716.8 \pm 52.0 \mathrm{ab}$ & $487.8 \pm 58.7 \mathrm{a}$ & $1114.7 \pm 103.3 \mathrm{a}$ & $593.5 \pm 64.1 \mathrm{a}$ & $1096.7 \pm 103.4 \mathrm{a}$ & $793.8 \pm 71.1 \mathrm{a}$ & $724.0 \pm 193.7 \mathrm{ab}$ \\
\hline GS:H2H & $455.5 \pm 70.5 \mathrm{a}$ & $684.7 \pm 123.1 \mathrm{a}$ & $590.5 \pm 82.9 \mathrm{a}$ & $853.5 \pm 79.8 \mathrm{a}$ & $557.0 \pm 61.4 \mathrm{a}$ & $969.2 \pm 115.6 \mathrm{a}$ & $485.7 \pm 66.6 \mathrm{a}$ & $862.0 \pm 103.0 \mathrm{ab}$ & $629.0 \pm 56.4 \mathrm{a}$ & $1026.8 \pm 112.9 \mathrm{a}$ \\
\hline P value & 0.014 & 0.884 & 0.489 & 0.004 & 0.791 & 0.177 & 0.004 & 0.023 & $<0.00001$ & 0.035 \\
\hline
\end{tabular}

*Means followed by the same letter are not significantly different based on Tukey's HSD test.



Figure 1: Average marketable and unmarketable strawberry yields for the observation period.

Results are promising in this first commercial field study with $\mathrm{H} 2 \mathrm{H}$. Although the nutritional value of $\mathrm{H} 2 \mathrm{H}$ was negligible low, the organic matter in the product might have supported the soil microbe colonies and indirectly improved the nutrient absorption. Significant amounts of applied nutrients can be lost in the environment resulting in negative impacts [7-9] and certain microbes can improve their uptake [10]. Bacillus spp., Pseudomonas spp. Glomus spp. and other bacteria and fungi promoted nutrient absorption in corn, cotton, wheat and other crops [11-13].

The manufacturer of $\mathrm{H} 2 \mathrm{H}$ later found several species of beneficial microbes in their formulation (Dan Morash, personal communication). Microbial activity and their impact on nutrient absorption was not within the scope of this study, but beneficial microbes in the formulation and/or in the soil might have played a role in nutrient absorption in $\mathrm{H} 2 \mathrm{H}$ treatments. $\mathrm{H} 2 \mathrm{H}$ formulation and recommendation rates have changed after the study was conducted. Additional studies in different fields with different application rates are essential to make valid conclusions as soil conditions and nutrient management practices vary among various fields.

\section{Acknowledgement}

Thanks to Daren Gee, DB Specialty Farms for the collaboration, California Safe Soils for the financial support, and Joe Coelho and Andres Tapia for their technical assistance.

\section{References}

1. Senesi N (1989) Composted materials as organic fertilizers. Science of the Total Environment 81: 521-542.

2. Tisdall JM, Oades JM (1982) Organic matter and water-stable aggregates in soils. European J Soil Sci 33(2): 141-163.

3. Baldock JA, Nelson PN (2000) Soil organic matter. In: Sumner ME (Ed.), Handbook of Soil Science. Boca Raton, FL, USA, pp. B25-B84.

4. Johnston AE, Poulton PR, Coleman K (2009) Soil organic matter: its importance in agriculture and carbon dioxide fluxes. Adv Agronomy 101: 1-57.

5. Chen JH (2006) The combined use of chemical and organic fertilizers and/or biofertilizer for crop growth and soil fertility. International workshop on sustained management of the soil-rhizosphere system for efficient crop production and fertilizer use. Land Development Department Bangkok, Thailand, Asia, 16: 20.

6. United States Department of Agriculture Economic Research Service (USDA-ERS) 2016. US Food Waste Challenge FAQ's.

7. Vitousek PM, Aber JD, Howarth RW, Likens GE, Matson PA, et al. (1997) Technical report: human alteration of the global nitrogen cycle: sources and consequences. Ecol Appl 7(3): 737-750.

8. Tilman D (1998) The greening of the green revolution. Nature 396: 211-212. 
9. Rodriguez H, Fraga R (1999) Phosphate solubilizing bacteria and their role in plant growth promotion. Biotechnol Adv 17(4-5): 319-339.

10. Adesemoye AO, Kloepper JW (2009) Plant-microbes interactions in enhanced fertilizer-use efficiency. Appl Microbiol Biotechnol 85(1): 1-12.

11. Egamberdiyeva D, Höflich G (2004) Effect of plant growth-promoting bacteria on growth and nutrient uptake of cotton and pea in asemi-arid region of Uzbekistan. J Arid Environ 56: 293-301.
12. Wu SC, Cao ZH, Li ZG, Cheung KC, Wong MH (2005) Efects of biofertilizer containing $\mathrm{N}$-fixer, $\mathrm{P}$ and $\mathrm{K}$ solubilizers and $\mathrm{AM}$ fungi on maize growth: a greenhouse trial. Geoderma 125: 155-166.

13. Shaharoona B, Naveed M, Arshad M, Zahir ZA (2008) Fertilizer dependent efficacy of Pseudomonads for improving growth, yield, and nutrient use efficiency of wheat (Triticumaestivum L.). Appl Microbiol Biotechnol 79(1): 147-155.

Your next submission with Juniper Publishers will reach you the below assets

- Quality Editorial service

- Swift Peer Review

- Reprints availability

- E-prints Service

- Manuscript Podcast for convenient understanding

- Global attainment for your research

- Manuscript accessibility in different formats

( Pdf, E-pub, Full Text, Audio)

- Unceasing customer service

Track the below URL for one-step submission https://juniperpublishers.com/online-submission.php 